\title{
RATING OF THE KORKYT ATA KSU IN THE CONTEXT OF ASSESSMENT OF EDUCATION QUALITY
}

\author{
Zhanna T. Zhaksylykova, Elena V. Milova, Zhanna B. Iztleuova \\ Korkyt Ata Kyzylorda State University, Kazakhstan \\ phone: +8 (7242) 262714, e-mail: korkyt_ksu@mail.ru
}

\begin{abstract}
This article discusses rating issues in the context of assessing the quality of higher education. In recent years, ratings have become an important attribute of the global educational services market. The main factor of the university's competitive success is its reputation in the national and international educational areas. Therefore, the institution chooses to participate in a particular rating based on its mission. The article tells about the experience of participation of the Korkyt Ata Kyzylorda State University in national and world rankings. It is noted that the worthy position of the Korkyt Ata KSU in the ratings is another confirmation and recognition of the quality of education in the university, the result of the painstaking work of the entire university staff. To improve the position of the Korkyt Ata KSU, the main directions are defined in the ratings.
\end{abstract}

Key words: education, quality of education, world rating, national rating, ranking of educational programs.

\section{INTRODUCTION}

The qualitative modernization of Kazakhstan, counting on the development of the "Smart economy", requires increasing the competitiveness and potential of the country's human resources. Therefore, it is not accidental that in the Message of the President of the Republic of Kazakhstan - the Leader of the Nation N. A. Nazarbayev to the people of Kazakhstan "New opportunities for development in the conditions of the fourth industrial revolution" the development of human capital is defined as a priority area [1].

The degree of development of the human resource is indicated by his education, which directly depends on the quality of education. One of the recognized mechanisms of quality assessment in the world are the ratings of educational institutions, primarily universities. Getting into the world or national rating on the leading places, the university dramatically increases its attractiveness not only for enrollees, but also for employers, investors and the state, which can provide it with additional grants.

High positions of the university at the global level represent a serious contribution to the formation of the image of the country, and as the educational services market becomes global, the level of human capital in the region is increasing, attracting investments, and increasing the share of educational services in the country's export structure. There are enough basis for this: according to the experts of the World Report on Monitoring Education and the International Institute for Educational Planning under UNESCO, currently more than 200 million students of the world in foreign universities are actively moving about 5.2 million people. At the same time, Germany and France account for up to $9 \%$ of the total number of foreign students, Russia - 5\%, while the United States and Great Britain attract about $40 \%$ of foreign students [2]. According to the Center for International Programs of the Ministry of Education and Science of the Republic of Kazakhstan today, there are only 12837 foreign students studying at the universities of the country, which is $0.2 \%$. Considering that the share of foreign students is one of the main criteria of world ratings, the Center sets the task to bring this figure to 50 thousand [3]. 


\section{AR'IIE

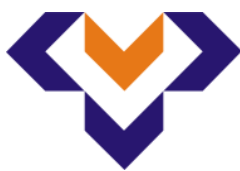

Ipplied Resseirl'hes in Technics, Technologies and Bductation

Journal of the Faculty of Technics and Technologies, Trakia University https://sites.google.com/a/trakia-uni.bg/artte/

\section{EXPOSE}

The main indicators of the effectiveness and quality of the university in most of the ratings are the effectiveness of its activities in such areas as education, science, internationalization and commercialization. However, despite the apparent similarity, the ratings are quite different - the set, the number of indicators being evaluated, and the weighting system, etc. Therefore, the institution chooses to participate in a particular rating based on its mission.

The mission of the Korkyt Ata KSU is the preparation of competitive and demanded specialists with higher and postgraduate education, focused on solving the issues of industrial and innovative development of all spheres of the economy of the Kyzylorda region and the Republic of Kazakhstan.

Proceeding from this, the strategic goal of our university is to get high positions in national ratings and to enter the world ranking of higher education institutions.

Annually Korkyt Ata Kyzylorda State University takes part in three ratings:

- National rating of the best universitiesin Kazakhstan;

- National rating of the demand for higher education institutions of the Republic of Kazakhstan;

- QS World University Rankings.

The National rating of the best universities in Kazakhstan is conducted by the Independent Kazakhstan Agency for Quality Assurance in Education (NKAO) since 2010. Educational institutions are represented in the following areas: multidisciplinary, technical, humanitarianeconomic, pedagogical, medical and high schools of art. For a comprehensive assessment of higher education institutions, three indicators are used. The first is determined by the parameters of the educational and research activities of universities, the second and the third - reputational, reflects the opinion of representatives of academic and scientific circles, the evaluation of employers.

The positions of Korkyt Ata KSU in the National rating of the best multi-profile universities in Kazakhstan are presented in Figure 1.

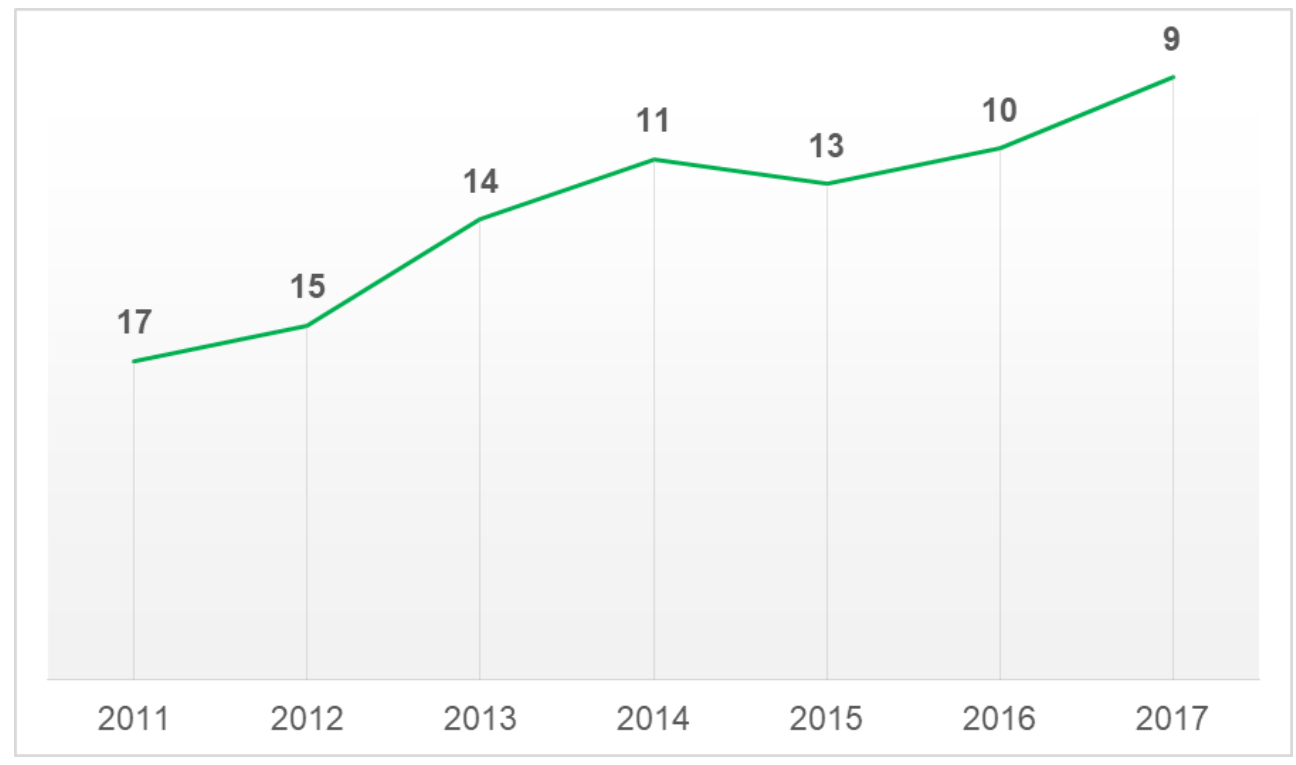

Figure 1. The positions of Korkyt Ata KSU in the National rating

The positive dynamics of the university's position in the rating is due to the improvement in the indicators for the following key criteria:

IRTIIE Vol. 6, No. 2, 2018 ISSN 1314-8788 (print), ISSN 1314-8796 (online), doi: 10.15547/artte.2018.02.018 


\section{IDTTIC Journal of the Faculty of Technics and Technologies, Trakia University https://sites.google.com/a/trakia-uni.bg/artte/}

- the number of educational programs (specialties) for training has been increased from 84 to 101 - Figure 2;

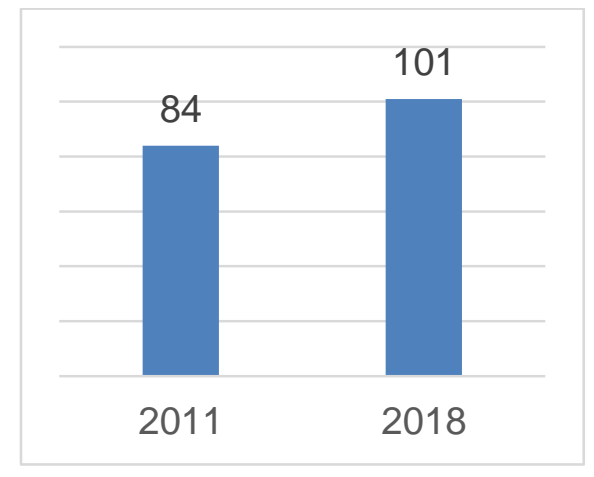

Figure 2. The number of educational programs

- the number of students-winners at scientific and practical conferences, olympiads in Kazakhstan and CIS countries (1-3 places) increased from 66 to 231 - Figure 3;

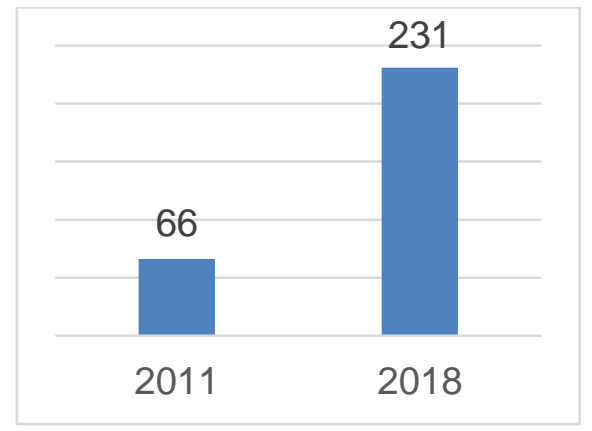

Figure 3. The number of students-winners at scientific and practical conferences, olympiads in Kazakhstan and CIS countries

- the number of student winners has been at scientific and practical conferences, olympiads in the far abroad increased from 0 to 62 - Figure 4;

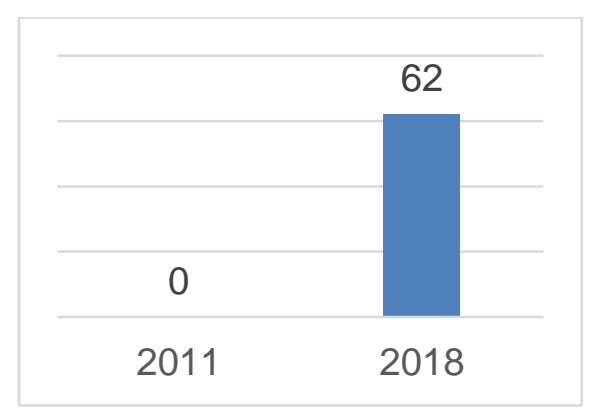

Figure 4. The number of student winners at scientific and practical conferences, olympiads in the far abroad

- the total volume of the funding of research works for the last calendar year (state and non-government funding, international grants) increased from 17,368,533 to 316,064 , 714 tenge - Figure 5;

IRITIE Vol. 6, No. 2, 2018 ISSN 1314-8788 (print), ISSN 1314-8796 (online), doi: 10.15547/artte.2018.02.018 


\section{IRTIIE}

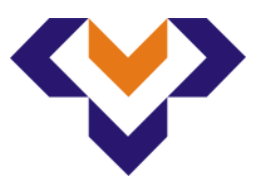

Ipplied Reserertches in Technics, Technologies and Bduration Journal of the Faculty of Technics and Technologies, Trakia University https:///ites.google.com/a/trakia-uni.bg/artte/

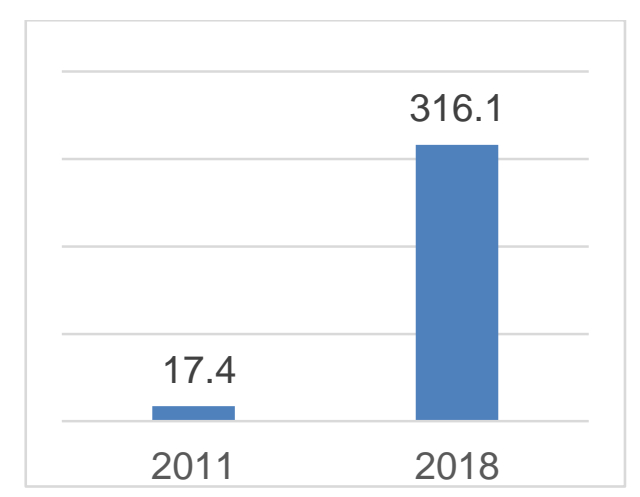

Figure 5. The total volume of the funding of research works for the last calendar year (state and non-government funding, international grants)

- the number of international exchanges, business trips (including Bolashak scholarships) for teachers and employees increased from 15 to 101 - Figure 6.

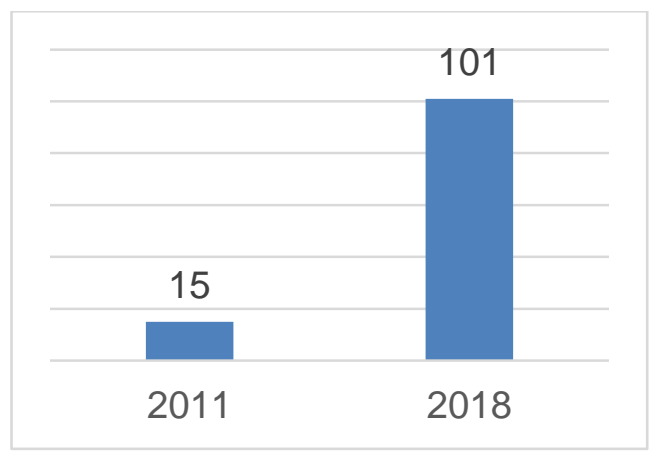

Figure 6. The number of international exchanges, business trips (including Bolashak scholarships) for teachers and employees

The national rating of the demand for higher education institutions in the Republic of Kazakhstan is being carried out by the Independent Accreditation and Rating Agency (NAAR) since 2014.

This ranking ranks the educational programs of universities on 4 indicators:

- high concentration of talented students, teachers and researchers,

- academic mobility,

- competitiveness of graduates,

- competitiveness of scientific publications of teachers, undergraduates and doctoral students of the specialty.

Annually, IAAR represents the top three ranking leaders of the Bachelor's, Master's and Doctoral programs, as well as the General rating in the areas of training specialists and Top 50 best university teachers.

Since 2014, the following three educational programs have consistently included the following educational programs of the Korkyt Ata KSU:

- 5B010400 Initial military training

- 5B011300 Biology

- 5B072900 Construction

- 5B073000 Manufacture of building materials, products and structures

- 6M011300 Biology

- $6 \mathrm{M011400}$ History

IRTITE Vol. 6, No. 2, 2018 ISSN 1314-8788 (print), ISSN 1314-8796 (online), doi: 10.15547/artte.2018.02.018 


\section{AR'IIE

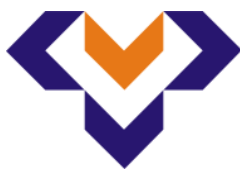 \\ Ipplied Resseirlohes in Technics, Technologies and Bductation \\ Journal of the Faculty of Technics and Technologies, Trakia University https://sites.google.com/a/trakia-uni.bg/artte/}

- 6M011700 Kazakh Language and Literature

- 6D073000 Manufacture of building materials, products and structures

Since 2015, our university has been actively participating in the world ranking of higher education institutions QS World University Rankings, which is calculated by the methodology of a British consulting company (Quacquarelli Symonds QS) and is considered as one of the most influential global rankings of higher education institutions.

Compilers of the rating use six evaluation criteria:

- academic reputation (the weight of the criterion in the rating is $40 \%$, calculated on the basis of an international survey of scientists);

- reputation among employers (10\%, calculated on the basis of an international survey of employers);

- ratio of faculty and students (20\%, data from universities and open sources);

- scientific citation of publications $(20 \%$, number of citations per article, calculated on the basis of Scopus / Elsevier data);

- the share of foreign teachers ( $5 \%$, data from universities and open sources);

- the share of foreign students (5\%, data from universities and open sources).

Annually, the agency analyzes the indicators of more than 2900 universities from 21 countries of the world, including the Czech Republic, Poland, Turkey, the CIS countries and the Baltic States and determines the TOP -300 best higher educational institutions of Eastern Europe and Central Asia (QS EECA).

In 2018 Korkyt Ata Kyzylorda State University entered the TOP-300 best universities, taking 273 places.

\section{CONCLUSION}

Thus, the worthy position of our university in national and world rankings is another confirmation and recognition of the quality of education in our university, as a result of the painstaking work of the entire KSU Korkyt Ata team. However, we must not stop at what we have achieved, we must make efforts to improve our positions in the ratings in the following areas:

- more actively implement joint educational programs with foreign universities;

- develop educational programs in English;

- attract foreign teachers and students;

- develop international academic mobility for students and university professors;

- expand joint research with foreign universities and research centers;

- commercialize scientific developments;

- as well as increase the number of publications of teaching staff and students in the world's scientific journals.

The implementation of these areas will, in our view, achieve positive dynamics in the development of the university.

\section{REFERENCES}

[1] Message of the President of the Republic of Kazakhstan - Leader of the Nation N.A. Nazarbayev to the people of Kazakhstan "New opportunities for development within conditions of the fourth industrial revolution"as of January 10, 2018.

[2] Why do we need university ratings. Rector of the Tomsk State University Eduard Galazhinsky on tactical assessments and development strategy // www.vedomosti.ru.

[3] Up to 50 thousand foreign students annually are planned to be attracted be the Ministry of Education and Science to higher educational institutions of Kazakhstan // Kazakhstanskaya pravdaas of November 17, 2017.

IRTIIE Vol. 6, No. 2, 2018 ISSN 1314-8788 (print), ISSN 1314-8796 (online), doi: 10.15547/artte.2018.02.018 